\title{
PREFACE: FOUNDER OF THE URAL SCHOOL OF THERMAL PHYSICS: TO THE 90TH ANNIVERSARY OF THE BIRTH OF ACADEMICIAN VLADIMIR SKRIPOV
}

As in the second issue of the journal Interfacial Phenomena and Heat Transfer, the third issue is also dedicated to Professor Vladimir P. Skripov (1927-2006), Academician of the Russian Academy of Sciences, and the founder of the Russian School of Thermal Physics, where he conducted research on metastable phase states (Fig. 1). In the preface to the previous issue (Baidakov, 2017), the main milestones of the scientific biography of Academician V.P. Skripov were highlighted. The preface to this issue shows the conditions that allowed Vladimir Skripov to implement his creative potential, as well as those qualities of his personality that turned him into an outstanding scientist and mentor of youth.

Vladimir Skripov was born on June 16, 1927, in Leningrad. For some time, the Skripov family lived in Arkhangelsk. In 1942, the family was evacuated to Veliky Ustyug of the Vologda Region, where in 1945 Vladimir graduated from secondary school with a gold medal. M. Bozhukova and A. Martyushev, classmates of Vladimir Skripov, characterized him as an honest, fair, and friendly person, who was respected in school. E.Z. Orlova, his literature teacher,

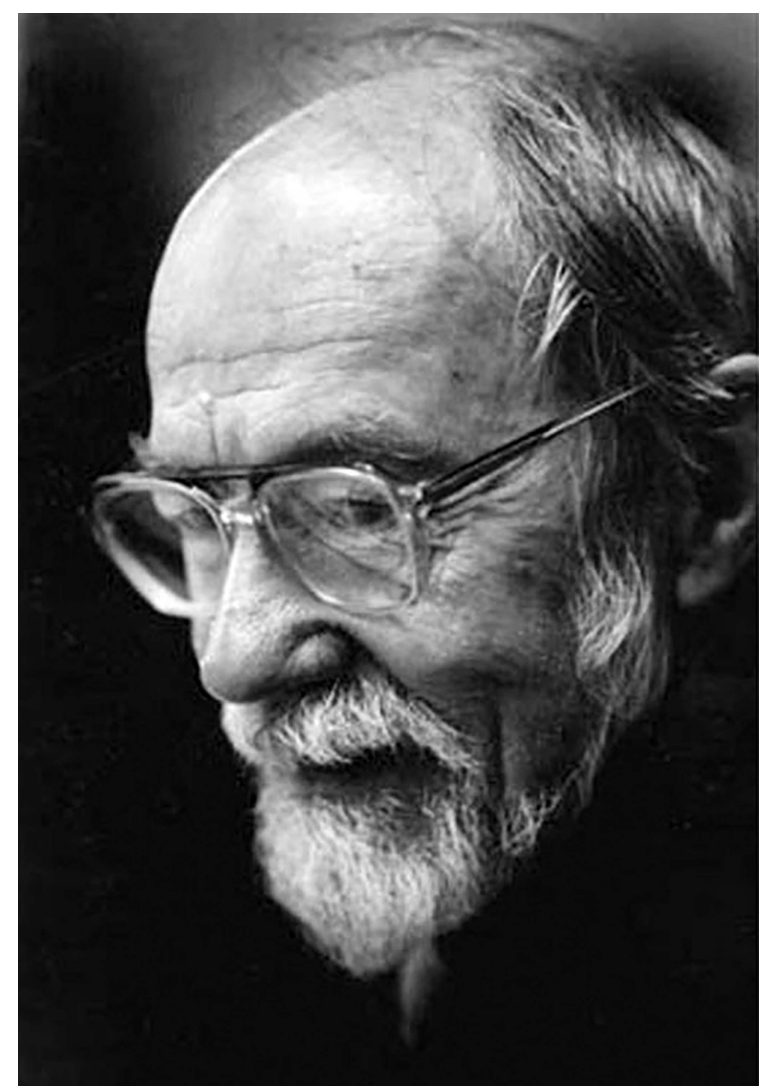

FIG. 1: Academician Vladimir P. Skripov (1927-2006) 
read his writings in the class due to their exemplary quality, and she was confident that Vladimir would choose literature as his specialty; however, Vladimir preferred physics (Bozhukova et al., 2007). Classmates noted that Vladimir Skripov loved classical music, especially Mozart's compositions. Even as a teenager, he was a creative, gifted person with diverse interests.

Vladimir Skripov wrote wonderful poems. By his own admission, "the poems were a part of biography, they reflected the moments of 'high tension' in the course of a measured life ... Poetry rejects daily routine of life ... Looking back, I see that many experiences and events are expressed in short and more clear in verse, than in the ordinary narrative" (Skripov, 1997).

In the summer of 1945, after the end of the Great Patriotic War, Vladimir Skripov entered the Physics Department at Moscow State University. The first post-war enrollment to the Physics Department was a record high and amounted to more than 300 people. In the era of modernization of the Soviet defense industry and the creation of new types of weapons, the demand for physicists was very high. Yu. Osminin, a fellow student, emphasized that at Moscow State University Vladimir Skripov also stood out among his contemporaries through his purposefulness and organization. In the mornings, before starting his day, he would first practice gymnastics, and always took a cold shower regardless of the time of year. In the evenings, after his classes, he initiated literary and philosophical debates, which were organized in his dorm room at the university (Bozhukova et al., 2007).

Moscow, with its magnificent theaters, gave students a great opportunity to join the world of art. Vladimir and his friends bought season tickets to the Great Hall of Conservatory and listened to concerts of great musicians such as David Oistrakh and Svyatoslav Richter. Thanks to the fact that theater prices were available even for students, Vladimir and his fellow students attended performances at the Bolshoi Theater and Moscow Art Theater. His passion for poetry brought Vladimir to the literary association of Moscow State University.

In his youth and as a student, Vladimir continued to develop his inner world. The creative personality is ready to accept new ideas better than others, and having assimilated them, to generate one's own ideas. This happened to Vladimir Skripov. Studying at the leading university of the country, he not only listened to the lectures of famous physicists, but also interpreted them creatively, and increased his scientific potential, which subsequently allowed him to reach fundamental achievements in his field of knowledge.

Vladimir Skripov, himself, and the people who knew him well, noted that Vladimir K. Semenchenko, Professor of the Physical Department, had a significant influence on the formation of his personality as a scientist. As a student at Moscow State University, Vladimir Skripov was specializing in studies at the Department of Molecular and Thermal Phenomena. V.K. Semenchenko suggested that he investigate the jump in heat capacity in some organic liquids during phase transitions of the second kind. The work was carried out in the laboratory of V.L. Pokrovsky, the closest colleague of V.K. Semenchenko. According to the recollections of E. Verny, a fellow student, Vladimir Skripov quickly discovered the expected effect and began studying it (Bozhukova et al., 2007). He successfully defended his diploma thesis and entered postgraduate studies at Moscow State University.

During his postgraduate studies, Vladimir Skripov performed a series of experimental works, which first determined the existence of a heat capacity maximum in stratifying liquid solutions. Together with the subsequent investigation of light scattering, these studies have made an appreciable contribution to the formation of the modern concepts regarding critical phenomena on the nature of fluctuation (Ermakov et al., 2006). In 1953, Vladimir Skripov defended his $\mathrm{PhD}$ thesis.

Later, Vladimir Skripov wrote: "My scientific interests were largely formed under the influence of V.K. Semenchenko. They can be defined by the key words: phase transitions, critical phenomena, thermodynamic stability" (Skripov, 1999). The young scientist was offered a position as an assistant in the Physics Department at Moscow State University. The world of metropolitan science was opened by Vladimir Skripov, but he was attracted by new horizons.

When Vladimir Skripov learned from Pavel Zyryanov, his fellow student, that a new Physical-Technical Department had opened at the Ural Polytechnic Institute (now Ural Federal University), the choice was made: Vladimir decided to move to Sverdlovsk (Yekaterinburg). Vladimir Skripov recalled: "All my friends did not understand the very formulation of the question: it is clear that you need to stay in the capital, at the Physical Department. Professor V.K. Semenchenko said that if he had offered his graduate student from Nalchik a place in Moscow, then he would have traveled a great distance on foot" (Skripov, 1999). However, in the autumn of 1953, Vladimir Skripov left for the Urals. At the same time, the scientific relation between the student and the teacher did not stop: when in Moscow, 
Vladimir would visit V.K. Semenchenko in his apartment in Lenin Hills. In commemoration of V.K. Semenchenko, Vladimir Skripov published several papers, where he highly praised the scientific talent of an outstanding scientist. In particular, in the article "War-scientist-book" he particularly emphasized that "V.K. Semenchenko was a contemporary of formation of the physics of atom and quantum mechanics; he knew the history of matter from the origin, and not from the secondary materials" (Skripov, 1992).

In Sverdlovsk, Vladimir Skripov taught at the Department of Molecular Physics, Ural Polytechnic Institute (UPI), for almost two decades, from 1953 to 1973. The Physical-Technical Department ("Fiztekh") at UPI trained engineers at the modern level, mainly for industrial enterprises in Russia. The best graduates of UPI went to science, and became lecturers at universities. Professor Vladimir Skripov was an example for students. Being a scientist and researcher, and highly intellectual person, he contributed to the formation of a creative environment as the chair and tried to awaken interest in scientific work in every student. At the Physical-Technical Department, V. Skripov for the first time prepared and delivered the following lecture courses: physical methods of isotope separation, physical chemistry, thermodynamics and statistical physics, analytical mechanics, among others.

About this period of his life, Vladimir Skripov wrote the heartfelt lines: "Looking back at the years I lived, I want to say that the Physical-Technical Department of UPI gave me the opportunity to fulfill myself as a researcher and teacher. Participation in the training of engineer-physicists for the nuclear industry, constant communication with students and post-graduates supported the spirit of search, prevented stagnation and complacency. At the PhysicalTechnical Department, I met good people. This has strengthened me in belief that the natural path of each case requiring collective efforts lies through benevolent cooperation" (Skripov, 1999).

Simultaneously with teaching, Vladimir Skripov was engaged in scientific research. Years later he recalled: "For several years in Sverdlovsk, I continued experimenting in development of what I did in the laboratory of my teacher. However, there was a desire to find a new topic of research with the prospect of obtaining results in the little-studied field of thermal physics. When in the 'Physics' abstract journal I got a brief article about the study of Japanese authors on observing the limit overheating of droplets of several substances (1958), I quickly realized the prospect of systematic study of liquids in a metastable state and immediately engaged in setting the experiments and involving students in this work. The topic was defined in 1961: metastable states of liquids (overheating, subcooling) and nonequilibrium phase transitions, accompanied by metastability. Since 1961, we have started publications of our results. There was a certainty that there were many interesting studies ahead, and new knowledge. So it happened" (Skripov, 1999).

For about a decade, an extensive program of studying various classes of liquids was fulfilled, generalizations were made and recommendations were given concerning the application of knowledge in laboratory and engineering practice. For non-equilibrium processes with phase transformations, the shock (explosive) boiling and crystallization regimes, characterized by intense fluctuations and the origin of a new phase, were distinguished. These results were the content of the Doctoral Thesis of V.P. Skripov "Metastable and supercritical states in the liquid-vapor system," which was defended in 1967. Two years later, V.P. Skripov was awarded the academic title of Professor (Ermakov et al., 2006).

Again, Skripov manifested the features of a creative personality with intuition and the ability to analyze and construct hypotheses, and to put them into practice. E. Matizen, an employee at the Siberian Institute of Inorganic Chemistry, characterized Vladimir Skripov as a brave man: "I was surprised when he dramatically changed the direction of his studies, moving to the study of metastable states in liquids. I did not expect then that his new work would become a powerful branch of science and lead to creation of the world famous school of Skripov and Academic Institute of Thermal Physics (Bozhukova et al., 2007).

Vladimir Skripov's academic activity began in 1965, when the Laboratory of Thermal Physics was founded in the Urals Branch of the Academy of Sciences of the USSR (now the Ural Branch of the Russian Academy of Sciences). The laboratory was established as part of the Department of Physical and Technical Problems of Power Engineering. In 1972, on the proposal of Academician S.V. Vonsovsky, Chairman of the Presidium of the Ural Scientific Center of the USSR Academy of Sciences, Vladimir Skripov headed this department. Over the next two decades, the study of the properties of highly superheated liquids and non-equilibrium processes accompanied by phase transitions was continued. Cryogenic liquids and their solutions in a metastable state were investigated in a large series of studies. 
The scientific school of Vladimir Skripov evolved naturally. His students from UPI became employees in the academic department, and then at the Institute of Thermal Physics of the Ural Branch of the Russian Academy of Sciences. According to the memoirs of A. Galashev, "Vladimir Pavlovich invariably showed interest in the work of each employee. He could give a piece of advice and valuable consultation at any time. The speed of his thinking was striking. He used to give a piece of advice 'to the very point' immediately. People from outside often heard: 'You are Skripov's, you all look like Vladimir Pavlovich.' We took this as a compliment”' (Bozhukova et al., 2007). Another student, V. Koverda, stressed that communication with V.P. Skripov "to the greatest extent, formed not only the attitude to science, but also to all other vital values" (Bozhukova et al., 2007).

Over course of time, the Department of Physical and Technical Problems of Power Engineering was transformed into the Institute of Thermal Physics. Skripov became its organizer and director during the period of 1988-1997. Thanks to him, the Institute of Thermal Physics of the Ural Branch of the Russian Academy of Sciences defined the correct scientific priorities, and increased and preserved the main potential in an era of radical social changes (Fig. 2).

The results obtained by V.P. Skripov and his team were highly appreciated by the scientific community. In 1981, he was awarded the Polzunov Prize of the USSR Academy of Sciences; in 1987, he was elected a Corresponding Member of the USSR Academy of Sciences; and in 1992, he was elected a Full Member of the Russian Academy of Sciences. In 1999, for a series of works on "Metastable states of liquids: fundamental research and applications to power engineering," a group of researchers headed by V.P. Skripov were awarded the State Prize of the Russian Federation in the field of science and engineering (Fig. 3).

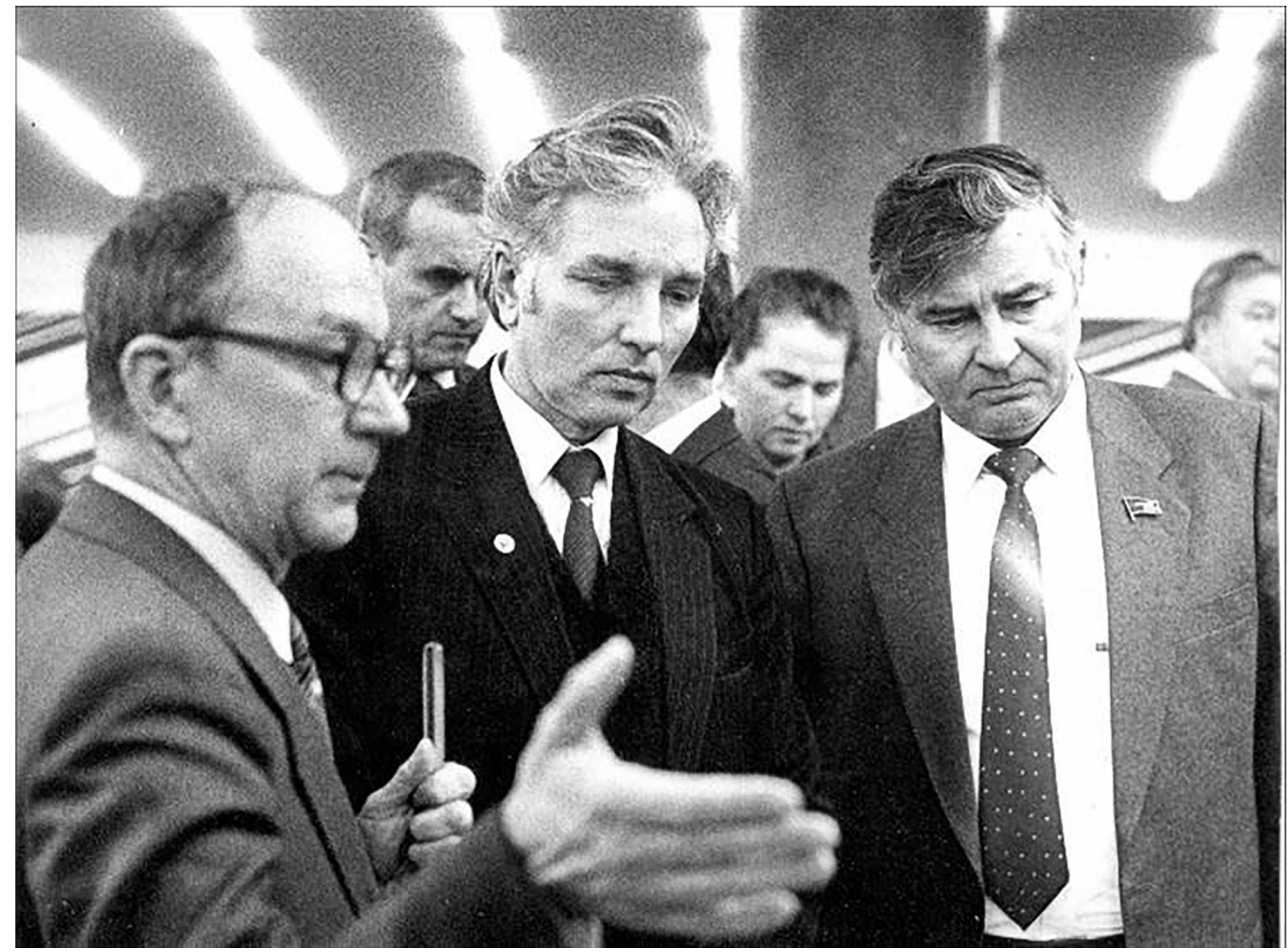

FIG. 2: Photograph taken at the presentation of the Institute of Thermal Physics (Sverdlovsk, 1990). From left to right, members of the Academy of Sciences: Vladimir Skripov, Gennady Mesyats, and Gury Marchuk 


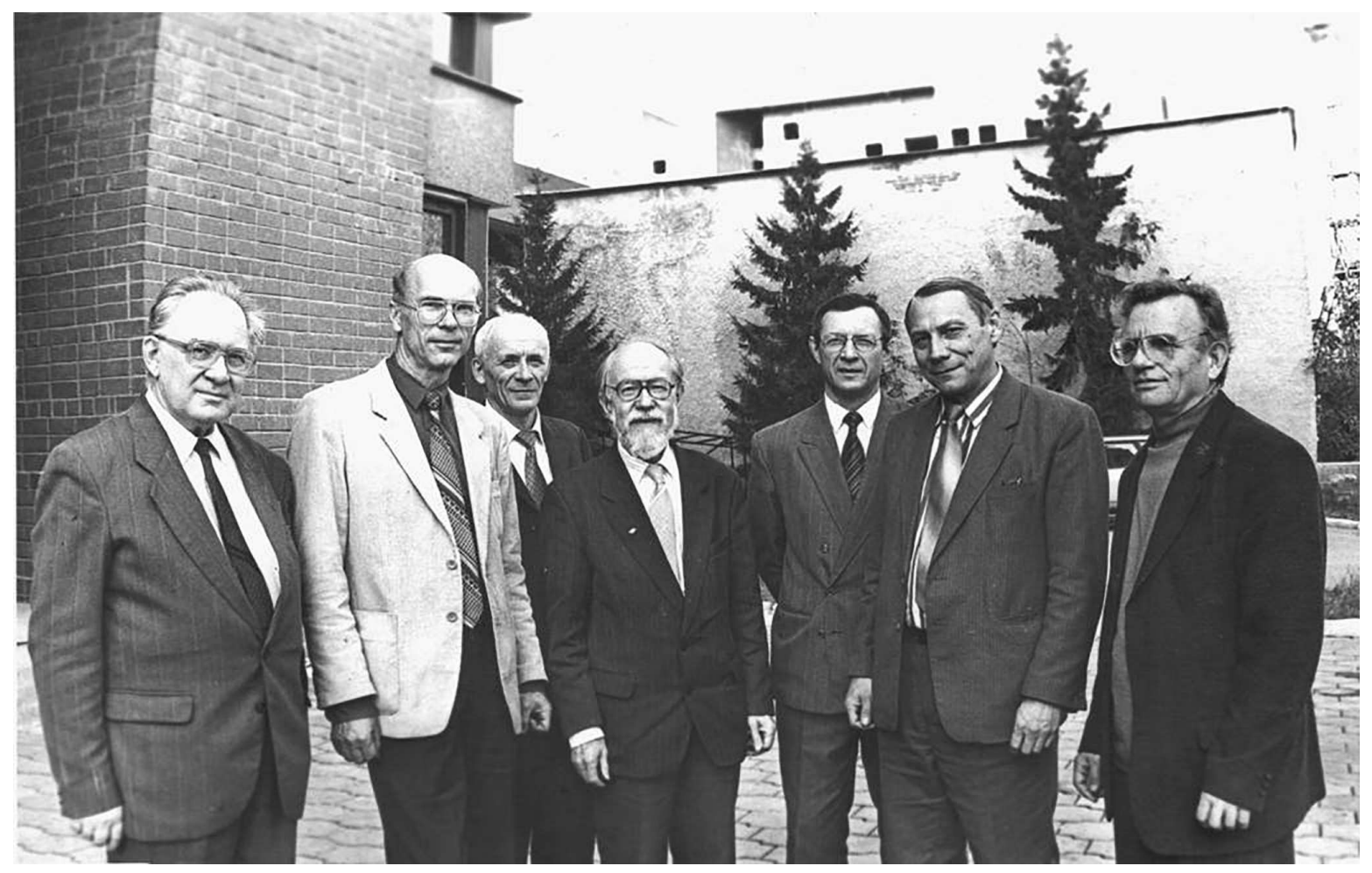

FIG. 3: Laureates of the State Prize of the Russian Federation in the field of science and engineering; Academician Vladimir Skripov is in the center, 1999

From the 1990s onward, Vladimir Skripov remained faithful to his chosen path. Seeing how Russian science was being destroyed because of lack of funding, he wrote articles in which he clearly expressed his civic stance. He believed that science, as an element of culture, and at the same time as the intellectual basis of material production, needed support from society and power structures. In the very scientific community, the actions for self-preservation must be activated. He believed that the most important among those actions was professional work aimed toward obtaining new knowledge about nature and society (Skripov, 1992). In the 2000s, the Institute became the leader of scientific research in its field of knowledge. Today, it is the largest center of thermophysical research in the Urals, which is conducted in four main directions: non-equilibrium processes with phase transformations; thermophysical properties of substances in stable and metastable states; heat transfer in energy-stressed processes; and thermophysical basis of energy-saving technologies.

In October 2017, the "Conference on Metastable States and Fluctuation Phenomena" (http://metastable2017.uran .ru/), dedicated to the 90th Anniversary of the birth of Academician V.P. Skripov, was held in Yekaterinburg. Representatives of the Russian scientific community, as well as scientists from Germany, Hungary, Ukraine, Japan, and the United States gathered at the Institute of Thermal Physics of the Ural Branch of the Russian Academy of Sciences. Conference participants took part in interesting discussions about the scientific avenues founded by Academician Vladimir Skripov.

Studies in the field of the physics of metastable phase states are being intensively developed both in Russia and internationally. The phenomenon of phase metastable states takes place through enhancement of heat and mass transfer processes in chemical apparatuses and nuclear reactors, when storing and transporting liquefied gases, in geysers and active volcanoes, as well as when stripping gas-condensate deposits (The Russian Academy of Sciences Ural Division, 2017).

In the continuation of discussions on these problems, the journal Interfacial Phenomena and Heat Transfer is publishing two special issues this year on "Metastable States and Fluctuation Phenomena" (issues Nos. 2 and 3), 
which are also dedicated to the 90th anniversary of the birth of Academician Vladimir P. Skripov. Papers from leading research teams in Russia, Germany, Hungary, Ukraine, and Japan present modern experimental and theoretical studies, as well as the results of computer simulations. The subjects of these papers deal with the metastable states of matter and nucleation, supercritical fluids, heat transfer and crisis phenomena at boiling, investigation of viscosity-pressure dependence, and the study of surface tension and contact angles on a partially wettable surface. These papers largely reflect the current state in the field of science, whose foundations were established in the works of V.P. Skripov.

Natalia A. Kupershtokh, PhD in History

Institute of History,

Siberian Branch of Russian Academy of Sciences,

Novosibirsk, 630090, Russia
Vladimir G. Baidakov

Institute of Thermal Physics,

Ural Branch of Russian Academy of Sciences, Ekaterinburg, 620016, Russia

\section{REFERENCES}

Baidakov, V.G., Academician Vladimir Pavlovich Skripov (1927-2006), Interf. Phenom. Heat Trans., vol. 5, no. 2, pp. v-iix, 2017.

Bozhukova, M., Martyushev, A., Osminin, Yu.P., Verny, E.A., Volobuev, P.V., Matizen, E.V., Koverda, V.P., and Galashev, A.E., To the 80th Anniversary of the Birth of Academician V.P. Skripov, Herald Ural Branch RAS, vol. 2, pp. 73-84, 2007 (in Russian).

Ermakov, G.V., Koverda, V.P., Pavlov, P.A., and Muratov, G.N., “The Good Will Come Back,” in Memory of Academician V.P. Skripov, Sci. Urals, vol. 11, pp. 4-5, 2006 (in Russian).

Materials of the Russian Academy of Sciences Ural Division, Physics of Metastable States: Current Trends, in Science of the Urals (vol. 23, p. 4), from http://uran.ru/sites/default/files/nu-pdf/nu_23_2017web.pdf, 2017 (in Russian).

Skripov, V.P., War-Scientist-Book, Her. Russ. Acad. Sci., vol. 5, no. 4, pp. 5-13, 1992 (in Russian).

Skripov, V.P., Irreversibility, Poems, Ekaterinburg, Russia: Ural Branch of Russian Academy of Sciences Publishing, 1997 (in Russian).

Skripov, V.P., "Fiztekh" in My Life, in Jubilee of “Fiztekh" of Ural State Technical University-UPI is Dedicated. 1949-1999, Ekaterinburg, Russia: Java, pp. 83-86, 1999 (in Russian). 